\title{
EDUCAÇÃO E BARBÁRIE: Por uma Economia Política das Desigualdades no Espaço Escolar
}

\author{
Ronaldo Queiroz Morais ${ }^{1}$
}

\section{RESUMO}

O presente artigo compõe uma leitura crítica que expõe os elementos de barbárie que habitam o social e a educação e que resultam de políticas de construção de desigualdades. A barbárie moderna consiste na produção de ambiente de placidez publicitária em meio à violência que impera. Sendo assim, a questão primeira da pedagogia crítica é a de desbarbarizar o espaço escolar a partir de estratégias e táticas de resistência e de transformação democrática com o propósito de garantir que Auschwitz não se repita.

Palavras-chave: Educação. Barbárie. Pedagogia crítica.

EDUCATION AND BARBARIANS:

For a political economy of inequalities in School space

\section{ABSTRACT}

This paper composes a critical reading which exposes the elements of barbarism that inhabit the social and the education and that result from policies of construction of inequalities. The modern barbarism consists in the production of a placid environment of publicity amid the violence that prevails. Thus, the first question of critical pedagogy is to debarbarising the school space from strategies and tactics of resistance and democratic transformation in order to ensure that Auschwitz does not repeat itself.

Keywords: Education. Barbarism. Critical pedagogy.

RECEBIDO EM: 2/7/2017

REVISÕES REQUERIDAS EM: 6/2/2018

ACEITO EM: 16/3/2018

\footnotetext{
${ }^{1}$ Docente de História do Colégio Militar de Porto Alegre (CMPA) e UniRitter Laureate International Universities RS - Curso de História e Relações Internacionais. Mestre em Integração Latino-Americana (UFSM) e doutor em História Social (USP). Orcid: https://orcid.org/00000002-6322-1500. ronaldoqueirozster@gmail.com
} 
Da exploração à exclusão, da exclusão à eliminação [...] será que essa sequência é impensável? Sabemos [...] que a barbárie, sempre latente, combina de maneira perfeita com a placidez daquelas maiorias que sabem tão bem amalgamar o pior com a monotonia ambiente (FORRESTER, 1997).

As grandes corporações dominam a economia e isso cria uma grande leva de pessoas pobres. O Estado deve apoiá-las, mas não quer ou não tem recursos. Por isso cria a ilusão de que, se você é pobre, a culpa é sua. Porque você não preencheu seu currículo direito ou chegou tarde a uma entrevista. Montam um sistema burocrático que te pune por ser pobre. A humilhação é um elemento-chave na pobreza. Rouba a sua dignidade e a sua autoestima (LOACH, 2017).

Desbarbarizar tornou-se a questão mais urgente da Educação hoje em dia (ADORNO, 1995).

Palavras de Mikhail Bakhtin: "cada signo ideológico é não apenas um reflexo, uma sombra da realidade, mas também um fragmento material dessa realidade" (1997, p. 33). A narrativa exposta aqui pretende percorrer o espaço escolar como um flâneur de olhar crítico-sensível. A partir dessa perspectiva, a escola, ao contrário da paisagem "entre muros", corresponde a espaço de re-produção de signos ideológicos dominantes (acadêmicos, culturais, econômicos e políticos) presentes em contexto social amplo a partir de produção de roupagem de universo próprio. Nesse sentido, quando observamos esse universo não colhemos apenas reflexo e sombra da realidade social, mas, fundamentalmente, fragmento material da ideologia dominante, que podemos sintetizar como a "barbárie" de nosso tempo, porém não é tudo. A escola - como dimensão pública - carrega as contradições que também estão manifestadas na totalidade da sociedade moderna, ou seja, além da reprodução da dominação hegemônica há a constante possibilidade de reprodução das estratégias e táticas de resistência desenvolvidas pelos diversos grupos sociais que lutam por igualdade e democracia. É essa dimensão pública que a pedagogia crítica absorve para o interior da escola a fim de educar para a emancipação. A ideologia é a condição que o poder hegemônico domina - porém ela jamais determina a dominação. O que caracteriza positivamente a sociedade moderna é - exatamente - a condição indeterminada de poder e a presença de utopia transformadora; afinal, tudo que é sólido se desmancha no ar na modernidade (a ideologia que oprime, também). Em absoluto, não estamos condenados à "jaula de ferro" da ideologia dominante.

A barbárie como tema associado à educação foi posta por Theodor Adorno como desdobramento de resistência pedagógica à violência brutal e racionalizante manifestada nos campos de extermínio nazi-fascistas e que ainda persiste na placidez publicitária que atua como cosmético que subtrai as desigualdades de nosso tempo. Nessa perspectiva, objetivamente, a educação deve inclinar-se para que Auschwitz não se repita jamais. A ideia-mestra é de que as estruturas modernas que produziram a barbárie dos campos de extermínio ainda estão de pé no coração do mundo contemporâneo. Adorno entende por barbárie, grosso modo, a presença de disformidade entre, de um lado, novas tecnologias e conhecimentos científicos e, de outro, uma sociedade tomada por agressividade e ódio primitivo em impulso de destruição - o que compromete a segurança da civilização (1995, p. 154). Assim, caminhamos em estrada perigosa, pois avan- 
ços tecnológicos e científicos produzem instabilidade quando há, na sociedade, imaginário social carregado de impulso destruidor e alienado o suficiente para assegurar, em termo nietzschiano, o "instinto de rebanho".

A monotonia ambiente da vida moderna no capitalismo tardio, ilustrada de publicidade por todos os lados, aparta-nos da real dimensão da barbárie que atravessa nossos corpos. A violência ordinária é banalizada - ora como acidente, ora como realidade incontornável da nova natureza do social imposta por forças divinas do capital, que transformam a vida coletiva e o cotidiano dos indivíduos em um inferno. Não há barbárie sem incremento das desigualdades; o desigual é o corpo fragilizado, abjeto que justifica a ação violenta e até mesmo o extermínio. É o "outro" do qual não há qualquer capitalização de cidadania ou dignidade humana; enfim, corpo de alteridade zero. Em ambiente hostil, a escola moderna, outrora protegida por muros seguros, agora carrega em seu interior, a partir de roupagem pedagógica, a barbárie que ordinariamente solapa as forças vivas com o propósito de manter o lucro abstrato. Educação e barbárie são polos que estão articulados no espaço escolar.

Sabemos bem, entretanto, que não há educação na barbárie, por isso desbarbarizar é questão fundamental de pedagogia que se constrói criticamente para transformar tanto o real quanto o simbólico, que barbariza e que se impõe como única realidade possível. Nas páginas que seguem, o esforço é o de desconstruir a ideologia dominante - que mensura a crise da escola moderna por meio da esfera neoliberal do "fraco desempenho" e que insiste na visão da crise como mera inadequação pedagógica diante de um mundo carregado de tecnologias informacionais. Para tal, centramos a narrativa crítica na economia política das desigualdades para explicitar a barbárie social que necessita ser contabilizada no espaço escolar. Trata-se de compor pesquisa qualitativa no campo da pedagogia da crítica a fim de demonstrar que os processos de produção de desigualdade produzem barbárie e que a violência da espoliação econômica interfere no fazer escolar.

\section{ELEMENTOS DE BARBÁRIE NA CONTEMPORANEIDADE}

Há elementos de barbárie na contemporaneidade que não podemos menosprezar. É a barbárie que se faz ordinariamente na produção de subjetividades centradas na indústria cultural a partir do esvaziamento do popular (do vínculo social) em benefício da massificação e da globalização dos sentimentos; na presença de mercado global totalitário e totalizante, que concentra absurdamente a renda mundial, destrói o Estado do Bem-Estar Social e isola o trabalhador na condição de indivíduo responsável por si em guerra de todos contra todos; no incremento da violência urbana produzida por jovens de gangues e terroristas como desdobramento do enfraquecimento dos vínculos institucionais e familiares; na guerra de drones e de acentuada tecnologia, que torna o combate obscenamente assimétrico; na emergência de Sociedade da Vigilância, que impõe câmeras de controle total sobre os indivíduos em seus movimentos privados e públicos; na violência e no ódio patente nas mídias sociais e tradicionais, que legitimam o crescimento de neoconservadores em escala global; e, finalmente, no horror social, que produz sofrimento psíquico e patologias de toda ordem. 
É pertinente desenvolver os elementos de barbárie no quadro de uma sociedade em que o alto nível tecnológico está - em larga medida - imbricado no processo de barbarização do social, e é nesse sentido que se impõe à educação contemporânea pensar estratégias de superação e resistência diante das ameaças alarmantes à civilidade moderna.

A sociedade moderna inflacionada de tecnologia produz um universo cultural em que as narrativas convergem para o mercado global. Assim, as mídias tradicionais (jornal, revista, rádio, televisão e internet) e as mídias sociais (Facebook) carregam a identidade de mercado global e a simplificação estética, como a essência dos produtos culturais fabricados pela indústria do consumo de massa. Na nova cartografia do lugar, não podemos menosprezar o volume-massa de corpos isolados, diante de écrans de todas as dimensões, consumindo imagens de grifes famosas e ódio de toda ordem - impossível imaginar o avanço de neoconservadores descolados dessas máquinas de guerra informacionais. Adorno e Horkheimer traduzem essa transformação com base no conceito de "indústria cultural", que atua como descrição teórica e analítica da experiência da cultura de massas e que transcende a mera ideia superficial e elitista de rejeição dos produtos culturais massificados como "má arte" (JAMESON, 1997, p. 191). Ou seja, o ponto central da indústria cultural não corresponde apenas à inconsistência do produto em si, mas ao processo reificante que produz cultura para o negócio - arrancando os vínculos sociais e o próprio sentido da arte na contemporaneidade. O elemento de barbárie está, objetivamente, no ato pedagógico de produção de subjetividade para o consumo cultural da indústria.

Nas palavras de Adorno e Horkheimer: "quanto mais sólidas se tornam as posições da indústria cultural, tanto mais brutalmente esta pode agir sobre as necessidades dos consumidores" (1982, p. 169-214). Em substância, o agenciamento ordinário não corresponde exclusivamente ao ato imediato de forjar consumo, mas ao impulso de cativar a própria subjetividade - ato pedagógico de violência simbólica com a intenção de formar consumidores para a indústria de bens. Há uma promessa de felicidade que subsiste no afã de mais consumo. A efemeridade dos produtos oferecidos é a regra dominante. Consoante Gilles Lipovetsky: "toda a cultura mass-midiática tornou-se uma formidável máquina comandada pela lei da renovação acelerada" (2009, p. 238). O descarte permanente da cultura e a frustração individual na premente busca da satisfação e felicidade, ofuscam o esclarecimento necessário para forjar estratégias de resistência positiva. A barbárie, assim, consiste na massificação da subjetividade, no hiperisolamento e na banalização do "Eu", objetivando a transformação do social em sociedade de consumo (o que não é o mesmo que "sociedade de consumidores", pois está localizada antes no esvaziamento da dimensão política da vida social - legitimando a ordem dominante - do que na extensão do consumo ordinário). É impossível imaginar todo o avanço da indústria cultural na contemporaneidade sem contabilizar a ofensiva do mercado global no capitalismo tardio. A colonização do lazer individual é produto de expansão totalitária e totalizante do capital que, em contexto de transformações tecnológicas de toda ordem, exerce pressão com a finalidade de desregular e flexibilizar estruturas burocráticas nacionais, regionais e locais, forjando as condições para a colonização absoluta. 
É nas dobras dessa indústria do lazer - no modo de produção de arte resistente - que convém indiciar a economia neoliberal como elemento de barbárie, na medida em que concentra renda e torna a miséria e a insegurança social uma realidade global. Nesse sentido, o recente filme de Ken Loach é seminal. Em expressão keynesiana, economistas tristes (hoje objetivamente neoliberais) com sua lógica insensível e irônica, desejam impor austeridade contra os trabalhadores e estudantes com a intenção de construir um estado frágil - vazio de obrigação social -, lançando a distopia no ar, da qual o filme "I, Daniel Blake" carrega cenas emblemáticas - ele não fala do não lugar, ou melhor, da ficção, trata da ferida social sangrando - atingindo a estrutura da sociedade; velhos, jovens e crianças desamparados de vínculos consistentes enquanto rentistas sugam o sangue das feridas sociais em benefício do lucro abstrato.

As cenas apresentam a opressão no ordenamento da plena "normalidade" - mesmo havendo evidente indício de barbárie social. O personagem principal, Dan (Daniel Blake), é um trabalhador sênior - homem de idade avançada que recebe a informação da burocracia estatal de que não faz jus ao benefício de saúde, mesmo tendo laudo médico que o impede de atividade laboral (enfermidade cardíaca grave). A burocracia fria e racionalizante (tal como a dos campos de concentração nazistas) procura assegurar que está tudo correto e dentro da legalidade. Há todo um aparato de tecnologia de informação que, antes de tornar o serviço de previdência social eficiente (internet e telefonia), atua como estratégia de dissuasão de direitos e cidadania, ou seja, há tanta impessoalidade moderna que desmobiliza a vontade de direitos sociais diante do labirinto de procedimentos e formulários. Dan, nas cenas seguintes, vai rapidamente perdendo a cidadania - chegando ao grau zero quando na iminência de passar à condição de morador de rua. Os demais personagens que orbitam em torno de Dan acentuam o sentido estrutural de pobreza e miséria. Há uma jovem-mãe solteira, residente em moradia precária, com dois filhos de ensino básico - desempregada - que enfrenta a dura realidade da procura do que - em realidade - não há: trabalho. O próprio conceito "desempregado" não é adequado no capitalismo tardio. Viviane Forrester já escreveu: "o fenômeno atual do desemprego já não é mais aquele designado por essa palavra" (1997, p. 10), exatamente porque não corresponde à fase da produção moderna em que o desemprego era uma condição passageira. Vivemos, portanto, uma época na qual a força motriz operária não é o foco fundamental do capital, e que a legislação de proteção das forças vivas atrapalha o lucro das empresas.

Como é possível viver quando não se é lucrativo ao lucro? Essa é uma questão importante posta diretamente por Viviane Forrester e na arte fílmica de Ken Loach. Tanto os personagens do filme quanto os trabalhadores de carne e osso, vivem desesperadamente num mundo em que a vida-não-está-bem diante da política de subtração de empregos e direitos trabalhistas. $O$ elemento de barbárie também corresponde à política de culpabilização dos pobres por sua condição de pobreza. Há a construção de ideologia "sem véu" tão bem denunciada por Ken Loach: "Os meios de comunicação falam de gente folgada, de viciados, de pessoas que têm muitos filhos, que compram televisores grandes Sempre encontram histórias para culpar os pobres" (2017). A barbárie alimenta-se da miséria. Impensável o exterminismo dos campos de judeus na Segunda Guerra sem antes o agenciamento racionalizante da miséria social. É nesse contexto 
que devemos compreender o incremento significativo da violência urbana, que carrega na vanguarda grupos de jovens nascidos nas feridas do capitalismo tardio: famílias monoparentais, de vínculos, moradia e renda precários.

A violência urbana é, essencialmente, juvenil - fruto de transformações importantes no modus vivendi das sociedades industriais e pós-industriais. A crise da família nuclear - que garantia laços afetivos e financeiros mais consistentes - e a presença cada vez mais acentuada - sobretudo entre pobres e miseráveis - de famílias monoparentais chefiadas por mulheres, enfraqueceram os laços fundamentais de garantia de certa estabilidade social diante de mercado ávido por lucro e de precariedade de postos de trabalho. O historiador Eric Hobsbawm (1995) pontua que, em 1991, 58\% de todas as famílias negras nos EUA eram chefiadas por uma mulher sozinha, e 70\% de todos os nascimentos de crianças negras tinham como genitora mulheres solteiras (p. 316), hoje realidade adaptada à paisagem social. Em regra geral, são jovens alijados do bem-estar moderno, mas ordinariamente agenciados para o consumo e por tribos urbanas de muitos matizes ideológicos - e essa condição proporciona laços de solidariedade com o grupo e violência desmedida às diferenças. Nas palavras do sociólogo Richard Sennett: "Nas sociedades humanas [...] o tribalismo pode revelar-se contraproducente. Sociedades complexas [...] dependem de circulação de trabalhadores através de fronteiras; contêm diferentes etnias, raças e religiões" (2013, p. 14). A lógica cosmopolita, inerente às cidades, é comprometida com o tribalismo - a violência urbana tanto produzida por jovens de gangues quanto por terroristas tem sua raiz no colapso do Estado do Bem-Estar Social, que produz miséria e fragiliza os laços institucionais (família/escola).

Efetivamente, esses jovens são marginalizados pela ordem vigente e sitiados em guetos, vivem no tempo morto, sem perspectiva de futuro e decepcionados com a fragilidade das instituições modernas diante do colapso do bem-estar que se evidência a cada nova proposta política de flexibilização de direitos que produz sempre menos cidadania. A violência urbana representada nas mídias (tanto sociais quanto tradicionais) subtrai a raiz do problema e isola a genealogia necessária para a compreensão da brutalidade que inflaciona as cidades. É como se a violência emergisse - do nada - do inferno para a terra - sem paternidade alguma. É preciso observar essa realidade dialeticamente. Viviane Forrester o faz quando afirma: "nesse contexto [...] suas brutalidades, suas violências são inegáveis. Mas as devastações de que eles são vítimas? Destinos anulados, juventude deteriorada. Futuro abolido" (1997, p. 61). A guerra urbana sem limites e regras - que ordinariamente vitima um número considerável de pessoas, em larga medida, não carrega diferenças significativas com a guerra em que atuam os Estados institucionais. O terror de Estado e a guerra urbana são de ordem semelhante. São jovens recrutados em ambos os lados e que devem fazer a violência prosperar sem horizontes claros de ação e de valores de combate.

A guerra como elemento de barbárie parecer ser um truísmo narrativo. Afinal, a guerra por si só não revela ato de barbárie? Absolutamente, não. Os conflitos belicosos acompanham as sociedades humanas, mas, a partir das "guerras totais" do século 20, há uma inflexão fundamental no uso da violência - ela perde o elemento político-cultural em benefício da técnica e das tecnologias. A lógica dos campos de concentração e das ofensivas militares é da mesma ordem; em poucas palavras, racionalização técnica 
insensível a qualquer valor humanitário moderno. Os conflitos internacionais envolvendo Estados e ONGs do Terror apresentam uma nova perspectiva belicosa. Com efeito, são guerras que rompem com a noção de soberania e de política internacional e que representam ameaça à liberdade e à democracia. A guerra perde o sentido específico moderno (ou seja, a guerra como continuação da política por outros meios) e transforma-se em fenômeno geral, global e sem espaço-tempo limitado de ação. Trata-se de guerra sem política objetiva - o que corresponde à "descarga total". A guerra passa a não ser uma exceção; agora é a regra inserida numa gramática militar que se estende por todo o corpo social. As ações belicosas que inauguram o século 21 promovidas pelos EUA e aliados contra Estados Soberanos de cultura islâmica, traduzem a guerra moderna em seu ápice. A guerra é absoluta. Em nome do terror, a desregulação das garantias internas de cidadania e o respeito diplomático para com os territórios ocupados são negligenciados. O aparato avançado de tecnologia militar é utilizado contra tudo e contra todos (mesmo cidadãos e países aliados) - as revelações de Edward Snowden (corpo terceirizado de informações secretas do Estado Americano) são emblemáticas. Os documentos, apresentados por ele, revelam, de um lado, o discurso burocrático normalizante acerca da barbárie e, de outro, o estado de vigilância total estabelecido pelos EUA a fim de conquistar informações de cidadãos americanos e da população civil planetária, além dos chefes de Estado, sem exceção de aliados ou inimigos.

Estamos vivenciando a transição do Estado do Bem-Estar Social para um Estado de Guerra Permanente - o que produz uma nova sociedade. De acordo com Michael Hardt e Antonio Negri: "sociedade na qual a diminuição das liberdades civis e o aumento dos índices de encarceramento constituem sob certos aspectos uma manifestação de [...] guerra social permanente" (2014, p. 39). As novas tecnologias - principalmente o uso desmedido de "drones" - produzem efeitos importantes sobre os combatentes. A insensibilidade é geral - o combate é monótono, carregado de tédio produzido pelas imagens do écran sobre o olho humano. As decisões militares são tomadas por milissegundos de tempo, em que não há discernimento seguro entre alvo militar e civil - os erros (mortes e feridos civis) são incorporados ao combate naturalmente. Há uma ruptura com a guerra clássica imaginada por Clausewitz - no sentido de dois Estados Modernos duelando. Segundo Grégoire Chamayou, "o paradigma não é o de dois lutadores que se enfrentariam, mas de um caçador que avança e uma presa que foge ou se esconde" (2015, p. 43).

O Estado Minimal de inclinação neoliberal que produz barbárie social, na guerra o faz em diapasão semelhante quando produz barbárie militar. A lógica é a mesma, a da inevitabilidade das forças de mercado e do poder da tecnologia. Tudo parece tão óbvio nas narrativas neoconservadoras e midiáticas - trata-se de ideologia sem véu. $O$ discurso também coloniza as ciências e avança no controle informacional. Para Paul Virilio: "a militarização da ciência com o complexo militar-científico e a militarização de toda a informação com o complexo militar-informacional colocam-se diante de um fenômeno de totalitarismo como nunca existiu" (2000, p. 38). É nesse contexto belicoso - de militarização do social e do político - que se estrutura uma nova sociedade. Uma "Sociedade da Vigilância", em que não há espaço de liberdade sólido - tudo é passível de controle no afã da obtenção de informações com a promessa de garantir a ordem e a segurança 
total. Distopia de uma sociedade baseada no medo e no ódio do dessemelhante - diferenças não digeridas de raça, cultura, religião, gênero e de classe - que põe a civilidade em risco e ameaça a democracia. Quando perdemos a perspectiva do bem-estar social, o medo passa a patologizar a sociedade. É o medo do desemprego, do desamparo social, do terror da alteridade, enfim, de ser descartado como sujeito de cidadania.

Vivemos a temporalidade morta da endocolonização já assinalada por Paul Virilio (1999), ou seja, depois da expansão global do poder do capital - agora a expansão de outro universo - da própria cidade em sua maior intimidade. Agora se deve cartografar o pequeno detalhe - olhar-máquina-obsceno. É a superexposição dos detalhes. Todos os atos sociais e individuais são cuidadosamente vigiados e controlados por agentes do governo e do mercado global (p. 106). A Sociedade da Vigilância conquista legitimidade graças ao medo do outro - o criminoso ordinário e, logo na sequência, o criminoso terrorista que apavora a ordem moderna. As tecnologias informacionais produzem um pseudoespaço social, onde a vida é vivida no isolamento de indivíduos diante das telas de sistema "pan-óptico". Diante disso, vigiar-e-ser-vigiado traduz uma gramática carregada de ideologia de mercado e de barbárie intelectual que ameaça os avanços moleculares progressistas e agencia cotidianamente as subjetividades modernas. O medo ante as incertezas da modernidade e o acentuado isolamento comunitário, reforçam o ódio e a ação política neoconservadora.

Do enfraquecimento político e da crise da representação partidária emergem as massas (ou maioria silenciosa), que, nesse momento, resolvem de forma atabalhoada fazer política atropelando a democracia. As fontes de informação advêm das redes sociais e da imprensa tradicional - não há senso crítico algum, apenas a vontade de confirmação de opiniões vulgares sobre a realidade. Ao contrário do passado, quando os partidos de massa absorviam e transformavam os desejos mais perversos em política, hoje as massas - segundo Jean Baudrillard - são de energia social fria (1985, p. 26). Os meios de comunicações desejam a ampliação das massas entre indivíduos isolados com o propósito de conduzir a voz da maioria silenciosa (opinião pública). As massas são carentes de alteridade - é característica do discurso de massa a negação de qualquer tentativa de salvaguardar as diferenças de gênero, de raça, de classe. As massas estão encerradas no patriotismo abstrato de tradição totalitária - posto que nega qualquer alteridade interna (o outro é sempre o inimigo). Há uma narrativa dominante permeada de positividade que associa o mercado global, os meios de comunicação e as massas (como opinião pública da maioria silenciosa). Sempre conjugados no mesmo enredo narrativo, independentemente das lutas dos movimentos sociais que estrondam o direito às diferenças. As ideias dominantes da época das massas são sempre as ideias das mídias dominantes. Ideologia sem véu a serviço das forças do mercado global.

Para finalizar, o último elemento de barbárie afeta a psique no corpo social - em implosão patológica geral. A progressiva extensão de violência positiva tem amparo germinal em sociedade de alto desempenho produtivo, proporcionando patologia neural. A paisagem patológica do social no século 21 está carregada de doenças neuronais: como depressão, transtorno de déficit de atenção/hiperatividade (TDAH) ou síndrome de Burnout (SB), fruto da violência da positividade, nas palavras de Byung-Chul Han, que resulta de superprodução, superdesempenho ou supercomunicação $(2015$, p. 16). 
Trata-se de violência que parte dos mecanismos de funcionamento do próprio sistema; não é viral (não vem de fora). Em outras palavras, parte de poder reificante de maximizar a produção. O capitalismo tardio exige velocidade e integração total dos corpos ao sistema global de produção e acumulação de riqueza. O tempo envolvido na atividade laboral é o mesmo do combate militar, sem limite. As novas tecnologias da informação proporcionam a absorção total das forças vivas na efetivação de trabalho morto (lucro abstrato).

\section{A ENDOCOLONIZAÇÃO DO MERCADO GLOBAL NO ESPAÇO ESCOLAR}

"Entre Muros" - essa paisagem da escola moderna hoje é uma ilusão. O espaço escolar é de produção e reprodução da vida social no contexto geral da sociedade vigente. Em outras palavras, o modo de produção da vida escolar está imbricado à macronarrativa do corpo social. O Estado Moderno é o locus ideológico e administrativo do ensino regular. É nesse corpo político institucional que a educação desdobra sua face. Em tempo de mercado global e de esbatimento de Estado de Bem-Estar Social, momento de transição para Estado de Inclinação Neoliberal, o espaço escolar passa por transformações importantes. A ideologia neoliberal atua como narrativa-mestra dessas transformações. A endocolonização do mercado global no espaço escolar representa contexto em que, para o capital, nada deve ser descartável a fim de exploração e acumulação. No extremo, tanto o próprio ato pedagógico quanto a privatização da água passam a ser objeto de obtenção de lucro. De fato, toda a tensão social e a violência presentes na mudança de paradigma de Estado e da própria sociedade, encontram seu equivalente na escola moderna. Todos os elementos de barbárie da sociedade contemporânea estão imbricados no modo de produção da vida escolar moderna. Os muros da escola não apartam estudantes e professores da insegurança, da incerteza e da violência ordinária que orbita o social no capitalismo tardio.

A escola moderna não está alijada da indústria cultural. Em realidade, é necessário imaginar o conceito como integrante de um verdadeiro complexo industrial-cultural que envolve produção de signos de consumo, compostos pela publicidade, pela indústria de show business, de informação, de lazer e podemos até ampliar para indústria de produção pedagógica. É uma indústria, antes, do entretenimento - no sentido de produzir a promessa malograda de bem-estar e felicidade a partir do consumo - do que da cultura como produção de arte ou mesmo cultura no sentido antropológico. É possível observar a endocolonização quando a cultura empresarial do consumo e da gestão investe contra os "muros da escola" com a intenção de reescrever a natureza da cultura infantil. Sublinha Henry A. Giroux: "torna-se claro à medida que as fronteiras que eram mantidas entre as esferas da educação formal e do entretenimento entram em choque" (2003, p. 127). Hoje o écran é o meio de manifestação mais frequente dessa indústria. As telas - em ideia vulgar - são as janelas do mundo. O mundo cabe nas telas? Obviamente que não. A representação do mundo nas telas, contudo, é tão real ou mais real que a própria realidade socialmente vivida.

O complexo industrial-cultural é a máquina de agenciamento das subjetividades no capitalismo tardio tanto na escola quanto fora dela. A indústria cultural encontra-se intumescida como totalidade. Há intensa adaptação e identificação com o existente e 
com o poder estabelecido, o que produz potencial totalitário (ADORNO, 1995, p. 44). No interior dos muros da escola a indústria cultural joga seu papel a partir de complexo agenciamento do próprio fazer pedagógico. O imaginário de crianças e adolescentes percebido, amiúde, no espaço escolar, é o criado pela publicidade. Assim, o imperativo do "seja didático" equivale à ideia de que alunos e alunas devem, antes de tudo, divertir-se. Essa promessa da indústria cultural, também malograda na sala de aula, produz muita frustração em docentes e discentes, pois a realidade é outra. Tal como nos campos de concentração, é impossível divertir-se ao ouvir Wagner diante de realidade tão bárbara. Os currículos, os materiais didáticos, as narrativas-mestras de temas e problemas de ensino, estão permeados de indústria cultural.

A presença desse complexo industrial de signos de consumo no espaço escolar e das jornadas longas diante das telas de agenciamento, revela a cartografia da qual professores e alunos convertem a vida sensível em tempo morto. O contexto contemporâneo de advento de máquinas de mídia interativa, cada vez mais sofisticadas, de capitalismo tardio de flexibilização de garantias sociais e da força de trabalho, produz uma geração de crianças e adolescentes criados e socializados por sistemas de produção de subjetividades e de esbatimentos de consciência política de classe, de gênero e de raça. Peter McLaren acentua que "não podemos esquecer que nosso investimento afetivo em objetivos materiais ou fetiches de consumo está vinculado às relações de produção e a uma política de consumo" (2000, p. 230). Ou seja, trata-se de sistema global de produção e reprodução da vida social baseado no capital abstrato e em políticas objetivamente neoliberais.

Além disso, há na escola de massa moderna uma acentuada preocupação com as teorias do cognitivo, mas paira um déficit importante para com as teorias das desigualdades. Afinal, por que os alunos e as alunas não aprendem? Há muito se sabe que - palavras de Richard Sennett - sociedades com altos coeficientes de Gini comprometem a realização educativa na grande massa dos alunos (2013, p. 170). Grosso modo, a ausência de uma economia política das desigualdades no espaço escolar é resultado de absorção acrítica das imposições da indústria do entretenimento, que totalitariza o universo escolar, reduzindo o problema ao ensino-aprendizagem - afinal, o bom vendedor vende tudo e em qualquer contexto. A ideia de que a crise da escola é fruto acentuado de inadequação desse espaço às transformações modernas, é muito publicitária para ser verdadeira. A crise da escola resulta antes da barbárie geral do capitalismo tardio (famílias desestruturadas e de vínculos frágeis diante do desemprego e da precariedade dos serviços de proteção social, do medo e do tédio da vida moderna) do que de inovações pedagógicas e de novas tecnologias.

A escola não está bem! O mundo está? É fundamental compreender o que há entre os muros da escola como resultado - em larga medida - da vida social e dos problemas vividos ordinariamente pela comunidade escolar para além dos muros da escola. No espaço escolar esses problemas tomam outra roupagem, que se traduz em apatia da aprendizagem, desmotivação, alienação diante das narrativas de ensino, sedução por tecnologias de écran e violência das diversas formas (do bullying às agressões físicas contra pessoas e patrimônio), resultando no baixo "desempenho" escolar. A realpolitik globalitária na pós-modernidade impõe como realidade naturalizada: o desempenho 
cobrado aos trabalhadores é o mesmo cobrado à comunidade escolar - afinal, o peso reprodutivo do capital exige desempenho de todas as forças vivas da produção. Dessa forma, a globalização e o esgotamento das políticas sociais que produzem desigualdades passam a ser uma realidade incontornável. O transpolítico impera, a política passa a ser a imposta pelo mercado e restrita à ação de gestão, a fim de adequar toda a realidade globalitária - as feridas do capital - à razão instrumental do capitalismo tardio. Eis a barbárie de nosso tempo. Tudo é uma questão de gestão, tal como nos campos de concentração. São os desiguais (marginalizados) que devem se adequar à dura realidade da política brutal, que, no imaginário totalitário, veio para ficar - afinal é o "fim da história" (Reich de mil anos). No coração das atuais reformas no ensino está o objetivo de transformar a educação em mercadoria, nas mesmas regras de flexibilização do mercado global.

Dessa forma, percebe-se um importante rompimento com a tradição liberal - que até então salvaguardou o espaço escolar da colonização do capital - posto que agora a educação é objeto de acumulação de riqueza em detrimento de formação da cidadania. Logo, as desigualdades naturalizadas no social e no político estão transpostas para a lógica escolar. A educação que representava "o outro do mercado" (SILVA, 1999, p. 8), agora assume a identidade do "mesmo do mercado", e passa a configurar-se como espaço de endocolonização, em que as forças de mercado interferem não apenas na construção de subjetividades dóceis, mas, fundamentalmente, na produção e reprodução das desigualdades a partir de ideologia "sem véu" que narra as desigualdades como resultado de processo natural da própria essência do "Eu". O filme "I, Daniel Blake" é, de certa forma, um grito de desespero desse "Eu" subjugado pelas forças do mercado global.

O Rap - canção popular dos guetos pós-coloniais - expressa nas letras relatos de vida marginalizada de bem-estar social. Com efeito, remete à violência urbana que compõe o contexto de barbárie contemporânea. Tendo emergido originalmente nos guetos americanos, em pouco tempo o Rap foi sendo apropriado por latinos, asiáticos e africanos como expressão de linguagem, de narrativa de dor e de sofrimento patente no cotidiano desses espaços descolados de cidadania moderna; território de vida social precária, em que o estado moderno apresenta-se antes como força repressiva do que de estabelecimento de bem-estar social. A violência policial, a guerra de gangues, o tráfico de drogas, a sexualidade explícita, são temas recorrentes no Rap.

No imaginário dos rappers afro-americanos, toda violência urbana presente nas canções corresponde à mensagem daqueles marginalizados pelo sistema dominante. O rapper é o mensageiro da dor e da angústia de jovens que, no capitalismo tardio, são desnecessários ao mercado globalitário como força produtiva. O rapper Chuck D. diz: "nós somos apenas os mensageiros, e como se pode matar os mensageiros? O melhor do rap é que ele é uma espécie de chance final, último aviso [...] um último pedido de ajuda, na contagem regressiva para o apocalipse" (MCLAREN, 2000, p. 154). O Rap é - tal como o Punk - expressão da arte e da cultura marginal. Trata-se de produção de linguagem da margem do sistema que relaciona a cultura afro-americana às feridas da pobreza moderna. Nesse sentido, os rappers são os mensageiros do caos social, mas também carregam em seus corpos toda a convulsão social da violência que inflaciona 
os guetos. Assim, semelhante aos punks urbanos, a violência é o objeto de denúncia e expressão de vida e de arte. A biografia dos rappers compõe a condição de sujeito e objeto da violência urbana. Por exemplo, os cantores de rap Dasean Cooper (J. Dee) e Terry Gray (T-Bone) foram acusados pela justiça de assassinato, e Tupac Amaru foi acusado de violência sexual e, posteriormente, assassinado em Las Vegas. Ao mesmo tempo em que carregam a "mensagem" de horror e denúncia da violência da qual foram objeto nos guetos americanos, também conduzem toda essa eletricidade da barbárie urbana em seus corpos. É nessa complexa topografia que é possível observar a violência urbana - crianças e adolescentes das escolas dos guetos globalitários carregam em si a violência que está nas canções de rap. São, de certa forma, rappers no espaço escolar, que trazem nos corpos toda a violência simbólica e física da burocracia e do mercado no capitalismo tardio e a transferem, amiúde, indistintamente para a sociedade. Em realidade, eles são rappers despossuídos de mensagem direta. A destruição do patrimônio e a violência física e simbólica contra colegas e professores manifesta-se no silêncio das palavras, na inflação de neologismos e na brutalidade da ação.

É por isso que é fundamental ouvir as canções dos guetos com a finalidade de leitura socioantropológica do espaço escolar a partir da "mensagem" do apocalipse trazida por esses anjos que vivem no inferno das grandes cidades. Essa violência urbana, carente de sentido político ou ideológico, sintetiza a barbárie. Ela se volta contra tudo e contra todos. Além disso, é necessário sublinhar que a violência urbana está concentrada nos guetos e que parcela importante dos jovens desses espaços dificilmente chega à idade adulta. As baixas dessa guerra urbana, localizada nos guetos, são consideráveis. Em regra geral, são jovens de baixo laço social familiar e comunitário - e que encontram nas gangues - por meio de rituais de iniciação e promoção no grupo - filigranas aparentemente sólidas para a existência precária da qual fazem parte. Por conta disso, a organização comunitária, e também a escola, são impotentes diante da solidez de laços sociais estabelecidos por essas ONGs da barbárie.

Como afirma Richard Sennett: "as gangues fazem com que os jovens se sintam pertencendo" (2013, p. 310). Esse pertencimento é resultado de fraca política de bem-estar social nos guetos urbanos que desencadeia a violência bárbara da qual os rappers são mensageiros, tomando de assalto violentamente a indústria cultural e violando o poder e a moral dominantes com a intenção de apresentar nosso apocalipse urbano. Para Viviane Forrester (1997), a escola é o território em que esses jovens estão ordinariamente, quiçá pela primeira vez, face a face com aqueles que os excluem (p. 75); em relação íntima, direta e compulsória com a burocracia insensível e racionalizante do Estado Neoliberal, que desdobra naturalmente a lógica da desigualdade e reproduz as forças excludentes que estendem muros ideológicos falaciosos entre professores que ensinam (ou que não sabem ensinar) para alunos que não desejam aprender.

A metáfora "Bomba Informática", elaborada por Paul Virilio, é seminal para fomentar o olhar crítico-sensível acerca da relação entre as tecnologias informacionais e a educação no capitalismo tardio. Trata-se de uma bomba que explode o modo de produção do social na modernidade, forjando uma sociedade nova, em rede. A coneç̧ão aparta os indivíduos do social no isolamento do "Eu" diante das telas informacionais. Em substância, as redes sociais são vazias de sociabilidade e de cidadania, uma vez que 
não há território no virtual, apenas simulacros de vida social. É necessário contabilizar o impacto dessa "bomba" nas subjetividades que comportam o espaço escolar. Os mais jovens são impactados diante das telas desde a escola maternal; são atingidos por patologias neurais das quais a dificuldade de atenção é a mais significativa. São imagens por todos os lados que aproximam obscenamente o real, anulando qualquer intimidade na inflação dos detalhes. Para Paul Virilio, representa a "endocolonização de um mundo sem intimidade, tornado estranho e obsceno, inteiramente entregue às técnicas de informação e à superexposição dos detalhes" (1999, p. 59). Nesse mundo carente de intimidade, a potencialização dos preconceitos sociais desdobra elementos de barbárie na escola moderna. O bullying é emblemático. O bullying resulta da intensa aproximação dos corpos insuflada pelas redes sociais e aplicativos de telefonia celular - o que expõe idiossincrasias intoleráveis diante da massificação da estética e dos sentimentos. Em síntese, emerge a violência que tem como epicentro a desigualdade e a intolerância contra os corpos que escapam da margem do grupo. Crianças e jovens seduzidos por telas informacionais, isolados diante de narrativas de informações publicitárias, reproduzindo a violência e o ódio, à alteridade em jogos virtuais e redes sociais. Além disso, é nesse contexto que inflacionam patologias neurais de campo amplo que indiciam dificuldade nas relações intersubjetivas e aprendizagem. Consoante Christian Dunker, "na educação, diagnostica-se cada vez mais cedo. A medicalização da infância passou da disfunção cerebral mínima, nos anos 1970, para a dislexia, nos anos 1990, chegando agora ao déficit de atenção" (2015, p. 20). Eles estão por demais conectados nas redes informacionais (pseudovias vazias de sociabilidade, de afeto e de cidadania), sem atuação política e presos à realidade social capturada pelo mercado e transformada em imagem publicitária.

A endocolonização do espaço escolar desdobra a barbárie que, ordinariamente, está na formação da acumulação de riqueza no capitalismo tardio. Em tempos de espoliação global, a colonização volta-se também aos espaços de fraca ação de mercado no passado. A escola, outrora restrita à produção funcional da burocracia moderna - na margem da "jaula de ferro" da administração nacional -, agora entra no campo do cálculo racionalizante do lucro abstrato e passa a reverberar a linguagem da sociedade do desempenho. Em nome do bom "desempenho escolar", do ensino para o século $21 \mathrm{e}$ para o contexto das novas tecnologias, estende-se a miséria pedagógica afinada ideologicamente com a nova ordem estabelecida, diante da qual não há nada a fazer a não ser adaptar-se à monotonia do tempo presente que suspende a barbárie do real, capturando a realidade pelo écran publicitário - nas telas a felicidade impera, mas na intimidade a dor é insuportável.

Vivemos uma época de precarização da vida social, de esgotamento do bem-estar, de crescente pauperização dos trabalhadores em benefício do mercado global - na qual os muros da escola não representam qualquer proteção. A desigualdade é a regra dominante. As teorias pedagógicas hegemônicas da sociedade do desempenho, porém, tangenciam a barbárie no afã de superar o sofrimento por meio de adaptação dos corpos à ordem neoliberal. 


\section{A PEDAGOGIA CRÍTICA E A ECONÔMIA POLÍTICA DAS DESIGUALDADES}

Para John Dewey (1959), democracia e educação estão imbricadas e uma sociedade democrática tem como imperativo a mudança, com o propósito de alcançar as promessas modernas de liberdade e igualdade. Nas palavras do autor: "uma sociedade que [...] faz da mudança um ideal terá normas e métodos educativos diferentes dos de outra que aspire meramente à perpetuação de seus próprios costumes" (p. 87). A democracia não corresponde ao simples ato formal e burocrático do voto, pois carrega ideais profundos de constante transformação progressista e histórias sociais de luta, a fim de incrementar a comunidade de cidadãos. Assim, a pedagogia crítica - que tem em Dewey a base sólida - elabora o pensamento pedagógico como resistência ao poder político hegemônico, que impede a realização do ideal democrático/igualitário, e no espaço escolar denuncia as pedagogias de ensino-aprendizagem que silenciam acerca desse ideal - abrindo campos de emancipação pedagógica. A escola é o lugar do saber, mas também espaço de exercício de poder.

Consoante Peter McLaren, "saber alguma coisa é sempre um efeito das relações saber/poder" (1997, p. 7); da mesma forma que não saber alguma coisa também corresponde, a efeito de relações de poder, a todo currículo (visível e/ou oculto) que subtrai a realidade social e econômica e que se descola do ideal democrático, fomentando a barbárie no campo pedagógico, na medida em que naturaliza todo sofrimento vivido cotidianamente e faz do espaço escolar mero campo de legitimação da exclusão e das desigualdades de toda ordem. $O$ ideal democrático na modernidade centra-se na perspectiva de igualdade. Assim, as políticas educacionais devem assegurar, segundo Dewey, "as facilidades escolares com tal amplitude e eficácia que [...] se diminuam os efeitos das desigualdades econômicas e se outorgue a todos os cidadãos a igualdade de preparo para suas futuras carreiras" (1959, p. 105). Na sociedade democrática deve-se educar para a igualdade, ao contrário da sociedade neoliberal, na qual se educa exclusivamente para o desempenho. Impossível pensar a educação para a democracia distante de políticas públicas de bem-estar social e de pedagogia que outorgue saber/poder aos grupos sociais que convivem na margem e na exclusão. Em poucas palavras, distribuição de riqueza e distribuição de saberes devem estar no centro das políticas verdadeiramente democráticas.

É nesse aspecto que se torna essencial o debate acerca da "economia política das desigualdades"; o conceito de "economia política" - posto por Rousseau como verbete na enciclopédia iluminista - já carrega uma longa tradição moderna. Em substância, trata-se da leitura crítica das políticas de distribuição e de acumulação de riqueza nas sociedades modernas, bem como da interação dos processos políticos e democráticos com as relações econômicas dominadas pelas forças do mercado global (BOTTOMORE, 1988, p. 118). A "economia política das desigualdades", portanto, insere-se na longa tradição moderna de avaliar os processos sociais a partir da crítica da política vigente que produz desigualdade. Os muros da escola moderna não a apartam das relações de poder dominantes - hoje neoliberais - que instauram naturalmente a desigualdade, fazendo dos estudantes de vida precária algozes de si (culpados pelo baixo desempenho escolar) e dos professores os únicos responsáveis pelo caos da escola pública. É nesse 
contexto que a pedagogia crítica joga papel importante, no sentido de fomentar e capacitar a comunidade escolar para o processo ensino-aprendizagem baseado em política emancipatória.

As teorias pedagógicas centradas no "cognitivo" imaginam o espaço escolar exclusivamente como lugar de ensino e aprendizagem, e, de certa forma, corroboram a paisagem da escola "entre muros" - alienada da espoliação ordinária que impera como realidade brutal imposta pelos mercados globais. Ao contrário, a pedagogia crítica - centrada na economia política - busca sobremaneira politizar a educação, demonstrando que as desigualdades produzidas pela política vigente e pelo mercado global são elementos importantes de barbárie no espaço escolar. Nesse sentido, há relação entre conhecimento, poder e dominação que não podemos menosprezar para que a educação possa ser crítica e radicalmente democrática.

De acordo com Henry Giroux: "a cultura escolar [...] funciona não apenas para confirmar e privilegiar os estudantes das classes dominantes, mas também, através da exclusão e insulto, para invalidar as histórias, experiências e sonhos dos grupos subordinados" (1997, p. 26). Sem dúvida, a linguagem do "fraco desempenho" escolar carrega elemento de barbárie, efetivamente porque violenta as forças vivas e oprime os grupos sociais de existência precária. $\mathrm{O}$ fracasso da aprendizagem é posto como mero colapso cognitivo.

A pedagogia crítica, contudo, impõe não apenas a crítica radical às desigualdades presentes no espaço escolar, mas também cria vias de possibilidades emancipatórias inéditas viáveis já apontadas por Paulo Freire. Diante de situação-limite no capitalismo tardio, é fundamental procurar "cadinhos" (dobras) de liberdade; para tal - como tão bem sublinha Giroux - é fundamental definir o espaço escolar como campo público-democrático e os professores como intelectuais transformadores. A escola deve, também, reproduzir todas as forças sociais progressistas de luta política a fim de desdobrar liberdade e democracia. O projeto moderno de educação lança o imperativo de romper com a menoridade a partir da emancipação dos sujeitos diante dos poderes que desejam conservar a tradição e a ordem.

Dessa forma, tanto homens quanto mulheres passaram a estar no campo da esperança de libertação social a partir de uma sociedade que caminha a passos largos para a liberdade e a igualdade. A educação passou a ser direito do homem moderno e a escola de massa foi o desdobramento da própria democracia de massas na modernidade triunfante. Malgrado, a universalização da educação, posta no século 20 , retirou todo e qualquer véu ideológico que cobria as desigualdades sociais no capitalismo tardio, frustrando a utopia moderna do "direito à Educação". Nas palavras de Francisco Imbernón, malograr no direito à educação significa que: "não só a vida de cada um empobrece e limita seu horizonte, mas também, dificilmente, podem ser realizados outros direitos, como a livre expressão, a participação política ou o direito ao trabalho nas sociedades avançadas" (2000, p. 46).

Em síntese, quando malogra o direito à educação resulta em barbárie. Para desbarbarizar a educação, convém conjugar a universalização do acesso à escola às políticas de transformação da realidade social a partir de espaço escolar que se faça antes reprodutor de políticas progressistas do que mero reprodutor de políticas de dominação. 
O espaço escolar compõe-se das mesmas contradições manifestadas na sociedade moderna. Os espaços modernos são contraditórios, e, além da dimensão e dos poderes de mercado, estendem-se laços públicos e democráticos. A escola também carrega essas mesmas contradições. Segundo Henry Giroux, "as escolas [...] reproduzem a sociedade mais ampla enquanto ao mesmo tempo contêm espaço para resistir à sua lógica de dominação" (1997, p. 28). O espaço escolar transcende ao simples lugar de ensino-aprendizagem. Há uma cultura escolar imposta ideologicamente pelo mercado global de tom neoliberal, na qual está no centro o imperativo do "desempenho". O conceito de "sociedade do desempenho" nos é esclarecedor; há nessa sociedade pós-moderna violência psíquica e cansaço endêmico. O que torna as baixas individuais regulares é, nas palavras de Byung-Chul Han, "o imperativo do desempenho como um novo mandato da sociedade pós-moderna do trabalho" (2015, p. 27). Esse imperativo também se apresenta no espaço escolar. $O$ processo ensino-aprendizagem desdobra-se no mesmo diapasão do "desempenho" como principal objetivo da educação. Os resultados referentes à aprendizagem são - amiúde - postos como pressão, com o objetivo de que a escola assuma antes política de gestão do que política pública e democrática - objetivando produção de corpos úteis para a sociedade do desempenho. Escolas, estudantes e professores de baixo desempenho - solução: novas políticas de gestão. Ou seja, trata-se, de forma administrativa, do que é político-pedagógico.

A barbárie que os estudantes vivenciam cotidianamente no capitalismo tardio e as desigualdades dos que apresentam baixo desempenho, não são contabilizadas diante da lógica insensível da burocracia neoliberal. É diante dessa paisagem que a pedagogia crítica se torna imprescindível, visto que é capaz de transformar o contexto opressor em texto político, ou melhor, narrativa de emancipação. Há uma natureza dialética no mundo moderno da qual a pedagogia crítica faz uso teórico. A pedagogia, nessa perspectiva, inclina-se teoricamente - leitura dialética - no reconhecimento de que a sociedade moderna é contraditória e desigual; da mesma maneira que compreende o espaço escolar como território que congrega contradições e desigualdades. Dessa forma, educar representa, de igual modo, tomar consciência de questões e problemas presentes na sociedade moderna e criar caminhos de liberdade para maior igualdade. No mundo em que a ideologia dominante perdeu seu véu, é preciso educar para resistir e transformar, na medida em que a exploração é tão obscena que não há véu ideológico que possa cobrir toda a barbárie exposta ordinariamente. Para Peter McLaren, "uma compreensão dialética da escolarização nos permite ver as escolas como locais de dominação e libertação" (1997, p. 200). Tal concepção mantém distância importante da teoria da escola como espaço de mera reprodução vulgar e absoluta do status quo, bem como das teorias do cognitivo e da educação para habilidades e competências com o propósito de produção de corpos adequados ao capitalismo tardio.

Impossível imaginar o espaço escolar descolado das novas tecnologias. A presença dessas máquinas informacionais na vida social e o imperativo ideológico de que, para aumentar o desempenho, elas são imprescindíveis, impõem no centro da relação ensino/aprendizagem as tecnologias que já inflacionam o mundo da produção no capitalismo tardio. Assim, o mundo realmente existente é, antes, virtual (das redes) do que real (da cidade). De fato, há uma inflexão que impacta as subjetividades, a qual não 
podemos menosprezar. Afinal, as telas seduzem e agenciam crianças, jovens e adultos de forma que o porcentual significativo do tempo diário deve ser contabilizado como tempo morto, consumindo as forças vivas da sociedade pós-moderna. Sendo assim, a questão fundamental das novas tecnologias - objeto de reflexão de Paul Virilio - não está na forma como utilizamos essas máquinas, mas essencialmente em como somos utilizados por elas. Em poucas palavras, somos ordinariamente capturados por essas máquinas a serviço da acumulação abstrata, de forma que o debate e o esclarecimento são fundamentais para evitar a barbárie geral.

A leitura e a escrita são as habilidades incontornáveis das práticas educativas; ler textos e contextos com a intenção de criar - como escrita política - novos textos e contextos. Os jornais operários do século 19 são emblemáticos para compreender o papel dessas habilidades como ato transformador e de resistência aos poderes dominantes. São habilidades antes artesanais do que industriais. Ler e escrever são habilidades modernas universais que sustentam a cidadania. São instrumentos que inserem os indivíduos no campo cultural e político - capacitando a todos a experiência e o contato com a civilização; habilidade que produz saber-poder quando de fato faz "ver e agir" sobre o mundo moderno com o objetivo de cumprimento das promessas de liberdade e igualdade. Segundo Francisco Imbernón, "os computadores, as redes pelas quais a informação flui não servem de nada aos analfabetos, pois estão povoados de letras mais do que qualquer outra coisa" (2000,p. 48).

Nesse sentido, a essência da educação permanece antes artesanal do que industrial. Ler e escrever são as ferramentas primordiais para que as novas tecnologias e as redes sociais possam ser ressignificadas por ação consciente de sujeitos críticos, para que se possa perceber, efetivamente, que não há tecnologia e rede social inocente. Para Paul Virilio, "quando alguém se priva da leitura e da escrita, priva-se da palavra e, portanto, do outro. [...] Esta necessidade social é fortemente ameaçada pelas tecnologias da informação" (2000, p. 70). No limite, o tempo morto das redes sociais e das novas tecnologias nos priva do diálogo público e da leitura de textos e contextos - nos priva do estar juntos da própria civilização. Com efeito, é necessário lembrar que aquilo que não nos civiliza, nos barbariza.

O território da pedagogia crítica exige a presença de professores que exerçam a docência como intelectuais. As sociedades democráticas estão alicerçadas na mudança constante e na transformação como resultado das lutas políticas. Sendo assim, a docência como intelectual distancia-se do professor "cabeça cheia" de saberes e reprodutor das ideias dominantes (intelectual tradicional), pois a postura deve ser a de "intelectual transformador"; professor que insere a pedagogia contra-hegemônica com a intenção de fortalecer os estudantes com saber-poder e habilidades significativas para atuar na sociedade pós-moderna e, também, capacita alunos e alunas para, no campo político, criar ações transformadoras (intelectual orgânico). Nas palavras de Henry Giroux, "isto significa educá-los para assumirem riscos, para esforçaram-se pela mudança institucional e para lutarem contra a opressão e a favor da democracia fora das escolas, em outras esferas públicas de oposição e na arena social mais ampla" (1997, p. 29). O professor intelectual transformador tem a "cabeça bem-feita" e atua organicamente desconstruindo o poder hegemônico na leitura crítica do significado das imagens que 
inflacionam as telas de todas as dimensões com a finalidade de transformar a sociedade, ampliando a igualdade e a democracia. A pedagogia crítica nasce da expansão da democracia moderna; ela é essencialmente alimentada pelo ideal democrático de igualdade. Para a vida democrática é fundamental encontrar as dobras do tempo que corre na sociedade do desempenho; é preciso parar e organizar a temporalidade para o debate público. Com efeito, é fundamental - como intelectual transformador - estender "barricadas" com o propósito de imobilizar a temporalidade morta do mercado global. Para Byung-Chul Han, "hoje vivemos num mundo pobre de interrupções, pobre de entremeios e tempos intermédios" (2015, p. 53).

É preciso que, diante do tempo que corre apressadamente na escola, os professores, como intelectuais, encontrem estratégias de resistência com o objetivo de brecar a rotina burocratizante e impor a parada necessária para a criação do pensamento crítico e ação democrática. A lógica da barbárie moderna consiste em isolar os desiguais e as desigualdades do sistema que a produz.

Para desbarbarizar, portanto, é necessário elaborar pensamento crítico que desfaça a monstrualização do outro que convive nas margens da cidade do capital. O papel do intelectual é o de acusar publicamente a barbárie como resultado de lógica perversa que impera na sociedade do desempenho e que na escola persiste em roupagem pedagógica.

\section{CONSIDERAÇÕES FINAIS}

Não há barbárie alijada do modo de produção de desigualdades. Assim, desbarbarizar corresponde à política de resistência e de transformação social diante da violência à qual as classes desamparadas são objetivamente expostas ordinariamente. De fato, o corpo barbarizado é o "outro" desigual que deve permanecer à margem dos privilégios econômicos da sociedade moderna. Educação e barbárie são horizontes conceituais polares - mas, na realidade cotidiana da escola de massa, estão imbricados. Os muros não isolam o espaço escolar da barbárie que regride a civilização moderna. A cegueira geral que negligencia as desigualdades na escola é elemento importante de barbárie, na medida em que subtrai todas as marcas de violência obscenamente presentes nos corpos que orbitam o espaço escolar.

A escola de massa carrega, em larga medida, os qualificativos da sociedade de massa. Consoante Freud, "a massa é extraordinariamente influenciável e crédula; é desprovida de crítica [...]. Ela pensa por imagens que se evocam associativamente umas às outras [...] e nenhuma instância razoável afere sua correspondência com a realidade" (2016, p. 50). No espaço escolar, independentemente da obscena desigualdade que explicita dor e desespero em tons diversos, a questão é sempre de ordem cognitiva. A ideologia neoliberal composta na "sociedade do desempenho" corresponde, na escola, ao discurso hegemônico de gestão pedagógica pronunciada por arautos do mercado com a intenção de produzir indivíduos atomizados e alienados politicamente, incapazes de perceberem a realidade perniciosa criada pelos rentistas globais. As imagens da publicidade e do poder político têm mesma identidade - são cosméticos do real. Assim, a barbárie real é substituída por práticas pedagógicas em que as normas, as avaliações regulares e as responsabilidades individuais de alunos e professores são de suma importância para legitimar o sofrimento e ingressar a todos no universo das desigualdades. 
É por isso que "desbarbarizar" tornou-se a questão mais urgente da educação, pelo menos para aqueles educadores que, no interior da pedagogia crítica, elaboram suas estratégias e táticas de ensino. A barbárie regride a civilização, pois impõe o impulso destrutivo às forças vivas do social - eliminando os laços civilizatórios de liberdade, igualdade e fraternidade, que são a base do projeto moderno. Dessa forma, acentua Adorno: "considero tão urgente impedir isto que eu reordenaria todos os outros objetivos educacionais por esta prioridade" (1995, p. 155). A educação que se insere como transformadora deve centralizar o pedagógico na percepção e denúncia das desigualdades e fomentar política de empoderamento dos barbarizados. Trata-se de uma pedagogia que busca retirar todo o cosmético que torna bela uma realidade violenta e obscena que as imagens publicitárias procuram esconder por meio de narrativas de poder neoliberais.

\section{REFERÊNCIAS}

ADORNO, Theodor; HORKHEIMER, Max. A indústria cultural: o iluminismo como mistificação de massas. In: LIMA, Luiz Costa. Teoria da cultura de massas. São Paulo: Paz e Terra, 1982. p. 169-214.

ADORNO, Theodor W. Educação e emancipação. São Paulo: Paz e Terra, 1995.

BAKHTIN, Mikhail. Marxismo e filosofia da linguagem. São Paulo: Hucitec, 1997.

BAUDRILLARD, Jean. À sombra das maiorias silenciosas. São Paulo: Brasiliense, 1985.

BOTTOMORE, Tom. Dicionário do pensamento marxista: verbete economia política. Rio de Janeiro: Zahar, 1988.

CHAMAYOU, Grégoire. Teoria do Drone. São Paulo: CosacNaify, 2015.

DEWEY, John. Democracia e educação: introdução à filosofia da educação. São Paulo: Cia da Editora Nacional, 1959.

DUNKER, Christian Ingo Lenz. Mal-estar, sofrimento e sintoma. São Paulo: Boitempo, 2015.

FORRESTER, Viviane. O horror econômico. São Paulo: Unesp, 1997.

FREUD, Sigmund. Psicologia das massas e análise do eu. Porto Alegre: L\&PM, 2016.

GIROUX, Henry A. Atos impuros: a prática política dos estudos culturais. Porto Alegre: Artes Médicas, 2003.

GIROUX, Henry A. Os professores como intelectuais: rumo a uma pedagogia crítica da aprendizagem. Porto Alegre: Artes Médicas, 1997.

HAN, Byung-Chul. Sociedade do cansaço. Petrópolis: Vozes, 2015.

HARDT, Michael; NEGRI, Antonio. Multidão: guerra e democracia na era do império. Rio de Janeiro: Record, 2014.

HOBSBAWM, Eric. Era dos extremos: o breve século XX (1914-1991). São Paulo: Cia das Letras, 1995.

IMBERNÓN, Francisco (org.). A educação no século XXI. Porto Alegre: Artes Médicas, 2000.

JAMESON, Fredric. O marxismo tardio: Adorno, ou a persistência da dialética. São Paulo: Unesp, 1997.

LIPOVETSKY, Gilles. O império do efêmero: a moda e seu destino nas sociedades modernas. São Paulo: Cia das Letras, 2009.

LOACH, Ken. El País: cultura. Disponível em: http://brasil.elpais.com/brasil/2016/10/22/cultura/1477145409_049665.html. Acesso em: 21 jan. 2017.

MCLAREN, Peter. Multiculturalismo revolucionário: pedagogia do discenso para o novo milênio. Porto Alegre: Artes Médicas, 2000.

MCLAREN, Peter. A vida nas escolas: uma introdução à pedagogia crítica nos fundamentos da educação. Porto Alegre: Artes Médicas, 1997.

SENNETT, Richard. Juntos: os rituais, os prazeres e a política de cooperação. São Paulo: Record, 2013.

SILVA, Tomaz Tadeu da. A escola cidadã no contexto da globalização: uma introdução. In: SILVA, Luiz Heron da (org.). A escola cidadã no contexto da globalização. Petrópolis: Vozes, 1999.

VIRILIO, Paul. A bomba informática. São Paulo: Estação Liberdade, 1999.

VIRILIO, Paul. Cibermundo: a política do pior. Lisboa: Teorema, 2000. 